\title{
29. ISOTOPIC ANALYSIS OF CORE GASES AT SITES 565-570, DEEP SEA DRILLING PROJECT LEG 841
}

\author{
Alan W. A. Jeffrey, Ronald C. Pflaum, Thomas J. McDonald, and James M. Brooks, Department of \\ Oceanography, Texas A\&M University \\ and \\ Keith A. Kvenvolden, U.S. Geological Survey, Menlo Park ${ }^{2}$
}

\begin{abstract}
Methane carbon-isotopic compositions $\left(\delta^{13} \mathrm{C}\right.$ values relative to the PDB standard) at Sites $565,566,567$, and 569 were lighter (enriched in ${ }^{12} \mathrm{C}$ ) than $-60 \%$, indicating a biogenic origin. In the deeper sections at Sites 568 and $570, \delta^{13} \mathrm{C}$ values were heavier, approaching $-40 \%$, and therefore suggest a thermogenic source. A significant thermogenic source was discounted, however, because the carbon dioxide $\delta^{13} \mathrm{C}$ values in these sections were also anomalously heavy, suggesting that the methane may have formed biogenically by reduction of the heavy carbon dioxide. $\delta^{13} \mathrm{C}$ values of ethane and higher hydrocarbons were measured in several sections from Sites 566 and 570 that contained sufficient $\mathrm{C}_{2}-\mathrm{C}_{4}$ hydrocarbon concentrations. Ethane values in six sections (245-395 m sub-bottom) from Site 570 were fairly uniform, ranging from -24 to $-26 \%$. These values are among the heaviest ethane values reported for natural gases. The isobutane/n-butane and isopentane/ $n$-pentane ratios of the core gases suggested that the $\mathrm{C}_{2}-\mathrm{C}_{5}$ hydrocarbons are thermally produced by low-temperature chemical diagenesis of indigenous organic matter. This process apparently generates isotopically heavy $\mathrm{C}_{2}-\mathrm{C}_{5}$ hydrocarbons. High gas concentrations in the serpentinite basement rocks at Sites 566 and 570 appear to have resulted from migrated biogenic methane gas containing small amounts of immature $\mathrm{C}_{2}-\mathrm{C}_{5}$ hydrocarbons.
\end{abstract}

\section{INTRODUCTION}

Carbon dioxide $\left(\mathrm{CO}_{2}\right)$ and methane $\left(\mathrm{C}_{1}\right)$ are the predominant carbon-containing gases in marine sediments. Both are present in overlying seawater, although $\mathrm{CO}_{2}$ in the form of dissolved bicarbonate has concentrations several orders of magnitude higher than $C_{1}$. Both gases are incorporated into pore waters of marine sediments from the overlying seawater, but important production and consumption reactions also occur within the sediment.

In near-surface sediments, the most important mechanisms affecting $\mathrm{CO}_{2}$ and $\mathrm{C}_{1}$ concentrations are biologi$\mathrm{cal}$. In the oxygenated zone, $\mathrm{CO}_{2}$ is produced from sediment organic matter during aerobic bacterial respiration. Below the aerobic zone, organic matter continues to be oxidized to $\mathrm{CO}_{2}$ during anaerobic bacterial respiration utilizing dissolved sulfate as the major electron acceptor (ZoBell and Rittenberg, 1948). Below the zone of sulfate reduction, bacteria consume bicarbonate-derived $\mathrm{CO}_{2}$ and produce $\mathrm{C}_{1}$. This reduction of $\mathrm{CO}_{2}$ to $\mathrm{C}_{1}$ may extend to considerable depths in the sediment column, and is evident in the generally parallel trends in carbon-isotope ratios of the two species below the zone of sulfate reduction (Claypool and Kaplan, 1974; Claypool and Threlkeld, 1983). A more detailed discussion of biologically mediated reductions in the upper sediment column is given by Rice and Claypool (1981).

Chemical reactions involving $\mathrm{CO}_{2}$ and $\mathrm{C}_{1}$ do not appear to be important in shallow sediments, except for the

\footnotetext{
${ }^{1}$ von Huene, R., Aubouin, J., et al., Init. Repts. DSDP, 84: Washington (U.S. Govt. Printing Office).

2 Addresses: (Jeffrey, Pflaum, McDonald, Brooks) Dept. of Oceanography, Texas A\&M University, College Station, TX 77843; (Kvenvolden) U.S. Geological Survey, 345 Middlefield Rd., Menlo Park, CA 94025.
}

chemical equilibrium between dissolved bicarbonate and solid carbonates, controlled predominantly by pore-water $\mathrm{pH}$. With increasing depth and temperature in the sediment column, chemical diagenetic reactions become increasingly important. Chemical decarboxylation of organic acids generates $\mathrm{CO}_{2}$, and $\mathrm{C}_{1}$ is produced by carbonbond cleavage in the thermogenic reduction of organic matter. Small amounts of higher hydrocarbons are produced during initial cracking of organic matter (Rice and Claypool, 1981). As sediment temperatures increase above $\sim 50^{\circ} \mathrm{C}$, thermogenic decomposition of organic matter generates increased amounts of methane and higher hydrocarbons which, if present in sufficient quantities, may form commercially exploitable liquid and gaseous hydrocarbon accumulations.

Much of the information on gases from thermally immature sediments comes from analysis of cores taken in the Deep Sea Drilling Project. Carbon isotopic ratios $\left(\delta^{13} \mathrm{C}\right.$ values $^{3}$ ) of $C_{1}$ in these cores, from a wide variety of DSDP sites, have been compiled by Claypool and Kvenvolden (1983). In most of the cores, $\delta^{13} \mathrm{C}-\mathrm{C}_{1}$ values are lighter (enriched in ${ }^{12} \mathrm{C}$ ) than $-55 \%$, indicating a biologically produced gas (Bernard et al., 1977). Methane heavier than $-55 \%$, which indicates a thermogenic origin (Fuex, 1977), was isolated from cores in areas of high geothermal gradients, such as the Gulf of California (Galimov and Simoneit, 1982). The higher temperatures at the bottom of these cores promoted thermogenic decomposition of the indigenous organic matter, generat-

${ }_{3} \delta^{13} \mathrm{C}$, \%o vs. PDB $=\left[\frac{{ }^{13} \mathrm{C} /{ }^{12} \mathrm{C}_{\text {sample }}}{{ }^{13} \mathrm{C} /{ }^{12} \mathrm{C}_{\text {std }}}-1\right] \times 1000$. 
ing isotopically heavy methane. Methane heavier than $-55 \%$ was also present in cores drilled above salt diapirs in the Gulf of Mexico (Claypool et al., 1973). In this case, the methane appeared to have migrated vertically with the diapir from more thermally mature sediments. These thermogenic occurrences are rather unusual in the DSDP cores, since most DSDP core gases come from low-temperature $\left(<50^{\circ} \mathrm{C}\right)$ sediments in which biologically produced methane predominates over the much smaller amount of thermogenic methane. The only evidence of nonbiological gaseous hydrocarbons at these sites is the small concentrations of ethane and higher hydrocarbons, since these are not direct products of the microbiological decomposition of organic matter (Claypool and Kvenvolden, 1983).

In this study gases in cores from Sites $565-570$ were analyzed for molecular and isotopic compositions. The core gases were predominantly $\mathrm{C}_{1}$, with generally less than one percent $\mathrm{CO}_{2}$, except at Site 570 , where $\mathrm{CO}_{2}$ concentrations were generally a few percent, with values up to $6.3 \%$. The $\mathrm{C}_{1} / \mathrm{C}_{2}$ ratios were $>1000$, except in several deeper sections, where up to $1.0 \% \mathrm{C}_{2}-\mathrm{C}_{5}$ hydrocarbons were present. Gases at the bottoms of the cored sections from Holes $566 \mathrm{C}$ and 570 were unique, as they were recovered from the basement rocks at these sites and so could not have been generated in situ from indigenous carbon. The gases presumably migrated into the basement rocks from an as yet unknown source.

\section{METHODS}

Gas pockets visible in the cores through clear plastic core-liners were tapped with a hollow punch, and samples were withdrawn into 20 -ml evacuated sample tubes (vacutainers). $C_{1}$ was separated from the other gaseous components by fractional distillation at liquid-nitrogen temperature, and combusted to $\mathrm{CO}_{2}$ in a system similar to that described by Sackett et al. (1970). $\mathrm{CO}_{2}$, ethane $\left(\mathrm{C}_{2}\right)$, and higher hydrocarbons were separated using a Carle Model 8000 gas chromatograph equipped with a silica-gel column, and individual components were isolated in traps packed with Poropak Q adsorbant at liquid-nitrogen temperature. In samples with sufficient higher-hydrocarbon concentrations, ethane, propane $\left(\mathrm{C}_{3}\right)$, and a combined fraction consisting of butanes and pentanes (designated the $\mathrm{C}_{4+}$ fraction) were isolated. The higher hydrocarbons were combusted to $\mathrm{CO}_{2}$ in the same system that was used for methane. Isotopic analysis of $\mathrm{CO}_{2}$ was performed on a Nuclide RMS 60 ratio mass spectrometer, and the results were reported relative to the PDB standard. Precision on replicate samples was better than $\pm 0.2 \%$.

\section{RESULTS AND DISCUSSION}

Methane isotopic values were obtained on vacutainer gases from Sites 565 through 570 (Tables 1 through 6). Methane isotopic profiles with depth for each site are presented in Figures 1 and 2. Carbon dioxide was present in sufficient quantities for isotopic analysis in vacutainer samples from Sites 568, 570, and one section from Site 565 (Tables 1, 4, and 6). Carbon dioxide isotopic profiles for Sites 568 and 570 are compared with methane isotopic profiles in Figure 3. Ethane and higher hydrocarbons were present in sufficient concentrations for isotopic analysis in only a few vacutainer samples from Sites 566 and 570 (Tables 2 and 6).

\section{Methane}

Methane isotopic values at Sites 565,567 , and 569 ranged from as light as $-88.2 \%$ at $59 \mathrm{~m}$ sub-bottom at
Table 1. Isotopic compositions and hydrocarbon isomer ratios of core gases, Hole 565 .

\begin{tabular}{|c|c|c|c|c|c|}
\hline \multirow{2}{*}{$\begin{array}{l}\text { Core-Section, } \\
\text { Interval } \\
\text { (cm) }\end{array}$} & \multirow{2}{*}{$\begin{array}{c}\text { Sub- } \\
\text { bottom } \\
\text { depth } \\
\text { (m) }\end{array}$} & \multirow{2}{*}{$\frac{\text { Isobutane }^{\mathrm{a}}}{\text {-butane }}$} & \multirow{2}{*}{$\frac{\text { Isopentane }^{\mathrm{a}}}{n \text {-pentane }}$} & \multicolumn{2}{|c|}{${ }^{13} \mathrm{C}\left(\%_{00}\right)$} \\
\hline & & & & $C_{1}$ & $\mathrm{CO}_{2}{ }^{\mathrm{b}}$ \\
\hline $6-6$ & 58 & 6.3 & 6.0 & -70.3 & \\
\hline $19-4,48$ & 177 & 6.8 & 24.6 & -65.9 & \\
\hline $21-3,126$ & 195 & 6.4 & - & -62.6 & -7.3 \\
\hline $22-6,86$ & 209 & 4.7 & 72.3 & -62.0 & \\
\hline $23-5,85$ & 217 & 6.0 & 36.2 & -61.5 & \\
\hline $24-3,61$ & 223 & 4.5 & - & -63.7 & \\
\hline $25-6,6$ & 238 & 5.3 & 33.3 & -61.4 & \\
\hline $26-4,14$ & 243 & 7.9 & - & -61.5 & \\
\hline $27-2,123$ & 251 & 7.0 & 41.7 & -63.2 & \\
\hline $29-2,149$ & 270 & 6.9 & 10.5 & -60.4 & \\
\hline $31-5,104$ & 293 & 7.7 & 25.0 & -62.6 & \\
\hline $34-1,96$ & 320 & 6.7 & 9.3 & -63.6 & \\
\hline
\end{tabular}

a A dash indicates that one or both components were not detected in the sample.

${ }_{\text {Isotopic analysis was not performed where insufficient } \mathrm{CO}_{2} \text { was present }}$ for measurement.

Table 2. Isotopic compositions and hydrocarbon isomer ratios of core gases, Hole 566C.

\begin{tabular}{|c|c|c|c|c|c|c|c|}
\hline \multirow{2}{*}{$\begin{array}{l}\text { Core-Section, } \\
\text { Interval } \\
\text { (cm) }\end{array}$} & \multirow{2}{*}{$\begin{array}{l}\text { Sub- } \\
\text { bottom } \\
\text { depth } \\
\text { (m) }\end{array}$} & \multirow{2}{*}{$\frac{\text { Isobutane }}{n \text {-butane }}$} & \multirow{2}{*}{$\frac{\text { Isopentane }}{n \text {-pentane }}$} & \multicolumn{4}{|c|}{${ }^{13} \mathrm{C}\left({ }^{10}\right)$} \\
\hline & & & & $\mathrm{c}_{1}$ & $\mathrm{C}_{2}$ & $\mathrm{C}_{3}$ & $\mathrm{C}_{4+}$ \\
\hline $6-1,121$ & 120 & 18.6 & 1.4 & -60.5 & -30.6 & -33.3 & -33.0 \\
\hline $7-1,90$ & 129 & 13.6 & 0.08 & -60.2 & -27.4 & -28.4 & -31.8 \\
\hline
\end{tabular}

Table 3. Isotopic compositions and hydrocarbon isomer ratios of core gases at Site 567.

\begin{tabular}{|c|c|c|c|c|}
\hline $\begin{array}{l}\text { Core-Section, } \\
\text { Interval } \\
\text { (cm) }\end{array}$ & $\begin{array}{l}\text { Sub- } \\
\text { bottom } \\
\text { depth } \\
\text { (m) }\end{array}$ & $\frac{\text { Isobutane }^{\mathrm{a}}}{n \text {-butane }}$ & $\frac{\text { Isopentane }^{\mathrm{a}}}{n \text {-pentane }}$ & $\frac{\delta^{13} \mathrm{C}\left(\%_{0}\right)^{\mathrm{b}}}{\mathrm{C}_{1}}$ \\
\hline \multicolumn{5}{|l|}{ Hole 567} \\
\hline H1-7, 2 & $1-176$ & 17.1 & - & -70.5 \\
\hline \multicolumn{5}{|l|}{ Hole 567A } \\
\hline H1-3, 142 & 1 & 17.3 & - & -70.0 \\
\hline $1-6,20$ & 203 & 4.8 & 68.0 & -70.5 \\
\hline $2-5,56$ & 212 & 5.8 & 19.7 & -70.7 \\
\hline $3-3,73$ & 219 & 5.5 & 55.0 & -70.9 \\
\hline $4-1,128$ & 232 & 5.1 & 17.0 & -72.9 \\
\hline $5-3,25$ & 237 & 4.7 & 12.2 & -72.6 \\
\hline $6-5,22$ & 250 & 41.0 & 21.6 & -72.4 \\
\hline $7-2,50$ & 255 & 3.8 & 10.3 & -72.8 \\
\hline $8-4,114$ & 268 & 3.7 & 78.0 & -73.1 \\
\hline $9-5,26$ & 278 & 3.7 & - & -71.8 \\
\hline $10-1,30$ & 281 & 4.0 & - & -72.7 \\
\hline $11-2,32$ & 291 & 4.2 & 4.2 & -73.2 \\
\hline $12-2,114$ & 301 & 3.1 & 11.4 & -71.5 \\
\hline $13-4,144$ & 313 & 3.0 & - & - \\
\hline $14-2,131$ & 319 & 3.5 & 17.3 & -72.3 \\
\hline $16-2,48$ & 336 & 3.2 & 9.6 & -70.8 \\
\hline $17-2,132$ & 346 & 3.5 & 10.8 & -72.0 \\
\hline $18-1,64$ & 352 & 1.4 & 0.6 & -72.0 \\
\hline $19-1,79$ & 360 & - & - & - \\
\hline $20-1,31$ & 377 & 0.7 & 0.8 & -70.6 \\
\hline $23-1,1$ & 412 & 2.5 & 0.7 & -66.9 \\
\hline $24-1,52$ & 421 & 2.3 & 2.1 & -71.4 \\
\hline $25-1$ & 430 & - & - & -57.9 \\
\hline $26-1$ & 439 & 2.6 & - & -61.0 \\
\hline $27-1,64$ & 446 & 1.5 & 2.6 & -73.8 \\
\hline $29-2,29$ & 486 & 3.0 & - & - \\
\hline
\end{tabular}

${ }^{\mathrm{a}} \mathrm{A}$ dash indicates that one or both of the components were not detected.

A dash here indicates that leakage reduced the concentration of methane below the level required for isotopic analysis. 
Table 4. Isotopic compositions and hydrocarbon isomer ratios of core gases, Hole 568 .

\begin{tabular}{|c|c|c|c|c|c|}
\hline \multirow{2}{*}{$\begin{array}{l}\text { Core-Section, } \\
\text { Interval } \\
\text { (cm) }\end{array}$} & \multirow{2}{*}{$\begin{array}{l}\text { Sub- } \\
\text { bottom } \\
\text { depth } \\
\text { (m) }\end{array}$} & \multirow{2}{*}{$\frac{\text { Isobutane }^{\mathrm{a}}}{n \text {-butane }}$} & \multirow{2}{*}{$\frac{\text { Isopentan }^{\mathrm{a}}}{n \text {-pentane }}$} & \multicolumn{2}{|c|}{$\delta^{13} \mathrm{C}\left(\%_{00}\right)^{\mathrm{b}}$} \\
\hline & & & & $\mathrm{C}_{1}$ & $\mathrm{CO}_{2}$ \\
\hline $3-5,30$ & 19 & 3.1 & 0.5 & -71.4 & -2.6 \\
\hline $4-4,43$ & 28 & 3.3 & 4.1 & -69.0 & +0.6 \\
\hline $5-5,89$ & 39 & 8.2 & 4.7 & -67.3 & +4.7 \\
\hline $6-4,30$ & 47 & 6.1 & 14.2 & -66.7 & +3.2 \\
\hline $7-3,142$ & 56 & 5.8 & 10.2 & -64.6 & +4.2 \\
\hline $8-5,95$ & 68 & 4.1 & 12.5 & -64.6 & +5.4 \\
\hline $9-4,128$ & 76 & 5.1 & 15.5 & -63.0 & +3.3 \\
\hline $10-4,82$ & 85 & 5.0 & 14.6 & -64.4 & +5.4 \\
\hline $12-4,101$ & 104 & 4.7 & 26.8 & -65.0 & +4.9 \\
\hline $13-4,128$ & 114 & 4.6 & 82.0 & -62.7 & +7.1 \\
\hline $14-6,32$ & 126 & 5.6 & 17.2 & -61.7 & +8.8 \\
\hline $15-6,54$ & 135 & 8.1 & 7.1 & -64.3 & - \\
\hline $16-4,131$ & 143 & 4.7 & 11.1 & -61.4 & +5.5 \\
\hline $17-4,125$ & 152 & 6.1 & 7.6 & -56.2 & - \\
\hline $18-3,43$ & 160 & 6.1 & 11.6 & -56.7 & +4.7 \\
\hline $19-7,46$ & 176 & 5.3 & 6.2 & - & - \\
\hline $20-6,58$ & 184 & 6.1 & 6.3 & -54.0 & - \\
\hline $22-5,105$ & 202 & 15.8 & 0.9 & -50.7 & - \\
\hline $23-2,89$ & 208 & 10.8 & 0.2 & -49.4 & - \\
\hline $24-4,20$ & 220 & 28.3 & 6.5 & -49.0 & - \\
\hline $25-6,2$ & 232 & 12.5 & 0.46 & -48.2 & - \\
\hline $27-3,52$ & 247 & 15.8 & 1.2 & -46.8 & - \\
\hline $28-4,98$ & 259 & 14.7 & 4.1 & -46.5 & - \\
\hline $29-5,93$ & 270 & - & 0.5 & -46.2 & - \\
\hline $30-6,127$ & 281 & 19.2 & 3.8 & -45.2 & - \\
\hline $32-6,85$ & 300 & 4.7 & 0.3 & -46.0 & - \\
\hline $33-6,101$ & 310 & 9.6 & 0.6 & -45.6 & - \\
\hline $34-6,39$ & 319 & 12.6 & 0.8 & -45.1 & - \\
\hline $35-4,107$ & 327 & 15.0 & 1.9 & -45.5 & - \\
\hline $36-6,93$ & 339 & 16.4 & 2.5 & -39.5 & - \\
\hline $37-4,30$ & 346 & 15.6 & 11.5 & -42.8 & - \\
\hline $38-6,69$ & 358 & 23.0 & 16.0 & -44.3 & - \\
\hline $39-3,34$ & 363 & 15.6 & 2.0 & -45.8 & - \\
\hline $40-3,86$ & 374 & 17.3 & 2.6 & -44.2 & - \\
\hline $41-5,117$ & 387 & 8.5 & 8.0 & -43.4 & - \\
\hline $42-6,117$ & 398 & - & 1.4 & -43.1 & - \\
\hline $43-4,40$ & 404 & 33.0 & - & -44.0 & - \\
\hline $44-4,97$ & 414 & - & 0.42 & -42.5 & - \\
\hline
\end{tabular}

a A dash indicates that one or both of the components were not detected.

b A dash here indicates that concentrations were insufficient for isotopic analysis.

Site 569 (the shallowest sample analyzed at this site) to $-57.9 \%$ at $430 \mathrm{~m}$ at Site 567 . These values are within the isotopic range of biogenic methane (Fuex, 1977; Bernard et al., 1977). The large predominance of methane over ethane at these sites, with $C_{1} / C_{2}$ ratios averaging several thousand, also indicates biogenically produced gas (Bernard et al., 1976).

At Sites 568 and 570, methane isotopic values indicative of biogenic gas were present in the upper 143 and $205 \mathrm{~m}$ of the cored sections, respectively. Below these depths, methane isotopic values became rapidly heavier, reaching fairly constant values of -40 to $-45 \%$ at the bases of the cored sections. Considered alone, these values indicate a gas of thermogenic origin, but the $\mathrm{C}_{1} / \mathrm{C}_{2}$ ratios do not substantiate this conclusion. For example, from 150 to $390 \mathrm{~m}$ at Site $568, \mathrm{C}_{1} / \mathrm{C}_{2}$ ratios averaged about 6400 , except for two samples from around $250 \mathrm{~m}$, in which methane was lost during sampling, accounting for the low $C_{1} / C_{2}$ ratios. At Site 570 between 205 and $395 \mathrm{~m}, \mathrm{C}_{1} / \mathrm{C}_{2}$ ratios were lower, averaging about 970 .

$\delta^{13} \mathrm{C}-\mathrm{CO}_{2}$ profiles at Sites 568 and 570 provide a possible explanation for the heavy methane values. As
Table 5. Isotopic compositions and hydrocarbon isomer ratios of core gases at Site 569 .

\begin{tabular}{|c|c|c|c|c|}
\hline Core-Section, & $\begin{array}{c}\text { Sub- } \\
\text { bottom }\end{array}$ & Isobutane $^{\mathrm{a}}$ & Isopentane $^{\mathrm{a}}$ & $\delta^{13} \mathrm{C}(\%)^{\mathrm{b}}$ \\
\hline & & $n$-butane & $n$-pentane & $C_{1}$ \\
\hline
\end{tabular}

Hole 569

$$
\begin{aligned}
& 5-4,85 \\
& 6-6,122 \\
& 7-7,45 \\
& 8-3,100 \\
& 9-1,45 \\
& 10-1,67 \\
& 11-2,66 \\
& 12-6,20 \\
& 13-3,45 \\
& 14-1,129 \\
& 15-3,83 \\
& 16-1,90 \\
& 17-6,41 \\
& 18-2,23 \\
& 20-1,134 \\
& 21-2,75 \\
& 22-2,55 \\
& 23-3,97 \\
& 24-5,75 \\
& 25-2,73 \\
& 26-5,20 \\
& 27-3,26
\end{aligned}
$$

\begin{tabular}{|c|c|}
\hline 1.2 & -79.9 \\
\hline- & -76.6 \\
\hline- & -74.4 \\
\hline 0.5 & -69.2 \\
\hline- & -67.9 \\
\hline 1.0 & -65.2 \\
\hline
\end{tabular}

36
49
59
63
66
79
90
105
110
117
129
136
153
156
175
186
195
207
219
224
238
244

$$
\begin{array}{r}
3.5 \\
\overline{3} .6 \\
10.3 \\
2.0 \\
11.5 \\
10.7 \\
33.5 \\
32.7 \\
17.0 \\
16.8 \\
- \\
\overline{1} .3 \\
- \\
26.0 \\
4.2 \\
33.0 \\
35.3 \\
\overline{30.0} \\
28.3
\end{array}
$$

$\begin{array}{ll}0.8 & - \\ 2.4 & - \\ -\overline{8} & -88.2 \\ 0.05 & - \\ 0.4 & -85.4 \\ 3.0 & -83.5 \\ - & -82.2 \\ - & -79.1 \\ 0.22 & -79.9 \\ - & -76.7 \\ - & -78.0 \\ - & -77.6 \\ 0.5 & -\overline{77.2} \\ - & -71.7 \\ 1.0 & - \\ - & -72.5 \\ - & -71.6 \\ - & -70.3 \\ - & -68.9 \\ - & -68.5 \\ - & -67.5\end{array}$

Hole $569 \mathrm{~A}$

$1-2,55$
$1-2,77$
$4-1,65$
$6-1,24$
$7-1,76$

248
258
275
294
304

25.5
9.0
18.5
5.7
11.4
8.0

a A dash indicates that one or both components were not detected.

b A dash here indicates that concentrations were insufficient for isotopic analysis.

shown in Figure 3, the isotopic profile of $\mathrm{CO}_{2}$ appears to parallel approximately that of $\mathrm{C}_{1}$, especially at Site 570 , for which more data are available. Carbon dioxide concentrations in vacutainers from sections below $284 \mathrm{~m}$ were too low for isotopic analysis, but isotopic analysis of bicarbonate from pore waters in these deeper sections (Claypool et al., this volume) has established that the $\mathrm{CO}_{2}$ isotopic trend does indeed follow that for $\mathrm{C}_{1}$ to the bottom of the cored section. This relationship indicates that the methane may not be thermogenic in origin, but may have been produced, as in shallower sections, by bacterial reduction of $\mathrm{CO}_{2}$.

A fractionation effect of approximately $-70 \%$ is involved in the bacterial production of $\mathrm{C}_{1}$ (Rosenfeld and Silverman, 1959). When $\mathrm{CO}_{2}$ has an isotopic value within its normal range of -15 to $+5 \%$, biogenic methane of -85 to $-65 \%$ is produced. Where $\mathrm{CO}_{2}$ is constantly being removed from a sediment system by reduction to $\mathrm{C}_{1}$, and addition of fresh, isotopically light $\mathrm{CO}_{2}$ from fermentation of organic matter is limited, $\mathrm{CO}_{2}$ would be expected to become progressively heavier. This trend would be reflected in the methane profile because the fractionation effect should remain constant. This process apparently is taking place in these cores, because Claypool et al. (this volume) have determined an isotopic value of about +30 to $+37 \%$ for bicarbonate at the bottom of 
Table 6. Isotopic compositions and hydrocarbon isomer ratios of core gases, Hole 570 .

\begin{tabular}{|c|c|c|c|c|c|c|c|c|}
\hline \multirow{2}{*}{$\begin{array}{l}\text { Core-Section, } \\
\text { Interval } \\
\text { (cm) }\end{array}$} & \multirow{2}{*}{$\begin{array}{l}\text { Sub- } \\
\text { bottom } \\
\text { depth } \\
\text { (m) }\end{array}$} & \multirow{2}{*}{$\frac{\text { Isobutane }^{\mathrm{a}}}{n \text {-butane }}$} & \multirow{2}{*}{$\frac{\text { Isopentane } \mathrm{e}^{\mathrm{a}}}{n \text {-pentane }}$} & \multicolumn{5}{|c|}{${ }_{8}^{13} \mathrm{C}\left(\$_{\infty}\right)$} \\
\hline & & & & $c_{1}^{b}$ & $\mathrm{CO}_{2}{ }^{\mathrm{C}}$ & $\mathrm{C}_{2}{ }^{\mathrm{c}}$ & $\mathrm{C}_{3}{ }^{\mathrm{C}}$ & $\mathrm{C}_{4+}{ }^{\mathrm{c}}$ \\
\hline $1-4,15$ & 5 & 5.0 & - & - & - & & & \\
\hline $2-5,59$ & 11 & 3.0 & - & -80.7 & - & & & \\
\hline $3-6,132$ & 22 & 3.9 & - & -78.9 & -8.3 & & & \\
\hline $4-2,117$ & 30 & 5.8 & $\overline{-}$ & -77.0 & $\begin{array}{l}-4.4 \\
\end{array}$ & & & \\
\hline $5-3,147$ & 41 & 0.4 & 0.5 & -75.6 & -4.1 & & & \\
\hline $6-5,55$ & 53 & 4.5 & - & -72.5 & -2.3 & & & \\
\hline $7.4,10$ & 61 & 6.1 & 14.0 & -71.1 & -1.5 & & & \\
\hline $8-3,55$ & 69 & 3.8 & 16.3 & -69.9 & - & & & \\
\hline $9-2,89$ & 78 & 4.3 & 12.5 & -69.3 & -2.7 & & & \\
\hline $10-2,143$ & 88 & 4.1 & 13.2 & -69.1 & -0.2 & & & \\
\hline $11-1,148$ & 96 & 3.7 & 17.1 & -68.3 & -1.1 & & & \\
\hline $14-5,27$ & 130 & 2.7 & 2.7 & -68.1 & 0.0 & & & \\
\hline $15-2,114$ & 136 & 13.0 & 5.2 & -67.8 & -0.1 & & & \\
\hline $16-6,8$ & 151 & 2.7 & 3.3 & -67.1 & +0.5 & & & \\
\hline $17-3,120$ & 157 & 2.1 & 11.2 & -65.8 & - & & & \\
\hline $18-1,138$ & 164 & 2.6 & 23.0 & -66.5 & 0.0 & & & \\
\hline $19-3,51$ & 176 & 2.2 & 18.7 & -65.1 & - & & & \\
\hline $20-1,106$ & 183 & 1.6 & 1.6 & -64.8 & +1.9 & & & \\
\hline $21-2,17$ & 193 & 3.2 & 6.0 & -63.0 & +4.3 & & & \\
\hline $22-3,84$ & 205 & 3.9 & 18.0 & -61.3 & +3.9 & & & \\
\hline $23-2,73$ & 213 & 3.9 & 7.7 & -56.6 & - & & & \\
\hline $24-3,54$ & 224 & 3.6 & 4.6 & -57.7 & - & & & \\
\hline $25-4,25$ & 234 & 1.8 & 1.1 & -55.5 & +4.8 & & & \\
\hline $26-4,148$ & 246 & 1.3 & 1.4 & -53.5 & +0.3 & -25.7 & -29.0 & \\
\hline $28-6.84$ & 267 & 1.3 & 3.9 & -40.8 & +10.7 & - & & \\
\hline $29-4,118$ & 274 & 1.1 & 4.8 & -42.8 & +9.9 & -25.6 & & \\
\hline $30-4,140$ & 284 & 4.4 & 7.4 & -42.3 & +16.3 & -24.2 & & \\
\hline $31-3,122$ & 289 & 1.3 & 3.4 & -42.2 & & & & \\
\hline $32-4,63$ & 302 & 2.1 & 2.3 & -42.1 & & & & \\
\hline $34-1,115$ & 318 & - & - & -41.4 & & & & \\
\hline $35-2,114$ & 329 & - & - & -41.8 & & & & \\
\hline $36-1,88$ & 337 & 10.0 & 2.4 & -41.2 & - & -24.9 & & \\
\hline $37-1,82$ & 346 & 6.8 & 2.6 & -41.3 & - & -24.3 & & \\
\hline $41-2,148$ & 387 & 8.2 & 0.8 & -41.2 & - & - & -21.4 & -22.6 \\
\hline $42-1,145$ & 395 & 6.6 & 2.7 & -40.2 & - & -24.3 & -21.6 & -26.0 \\
\hline
\end{tabular}

the cored sections from Sites 568 and 570 . Bacterial reduction of this heavy $\mathrm{CO}_{2}$, with a fractionation effect of about $-70 \%$, would produce methane with an isotopic value of about $-40 \%$, as is in fact observed.

\section{$\mathrm{C}_{2}-\mathrm{C}_{5}$ Hydrocarbons}

Ethane and higher hydrocarbons, which generally increase in concentration with depth in these and other DSDP cores (Rice and Claypool, 1981), are thought to result from both diagenesis of the indigenous organic matter in the sediments (Claypool and Kvenvolden, 1983) and/or upward migration from deeper, more mature strata (Summerhayes and Gilbert, 1981). There is strong evidence for migration of hydrocarbons into the rocks sampled at 120 and $129 \mathrm{~m}$ in Hole $566 \mathrm{C}$, and at 387 and $395 \mathrm{~m}$ in Hole 570. These sections contain basement rocks, serpentinite, in which the hydrocarbons would not have been generated, but had appreciable concentrations of $\mathrm{C}_{2}-\mathrm{C}_{5}$ hydrocarbons (up to $1.0 \%$ ), with $\mathrm{C}_{1} / \mathrm{C}_{2}$ ratios ranging from 85 to 420 . Although the isotopic ratios from these sections indicate that the methane is predominantly biogenic, the $\mathrm{C}_{2}-\mathrm{C}_{5}$ hydrocarbon trends seem to indicate a significant thermogenic gas component. For example, in Hole 570, ethane and higher hydrocarbons increase with depth to $274 \mathrm{~m}$, decrease rapidly between 274 and $328 \mathrm{~m}$, and then increase to the bottom of this hole. This concentration profile is evident in the $C_{1} / C_{2}$ ratios, which

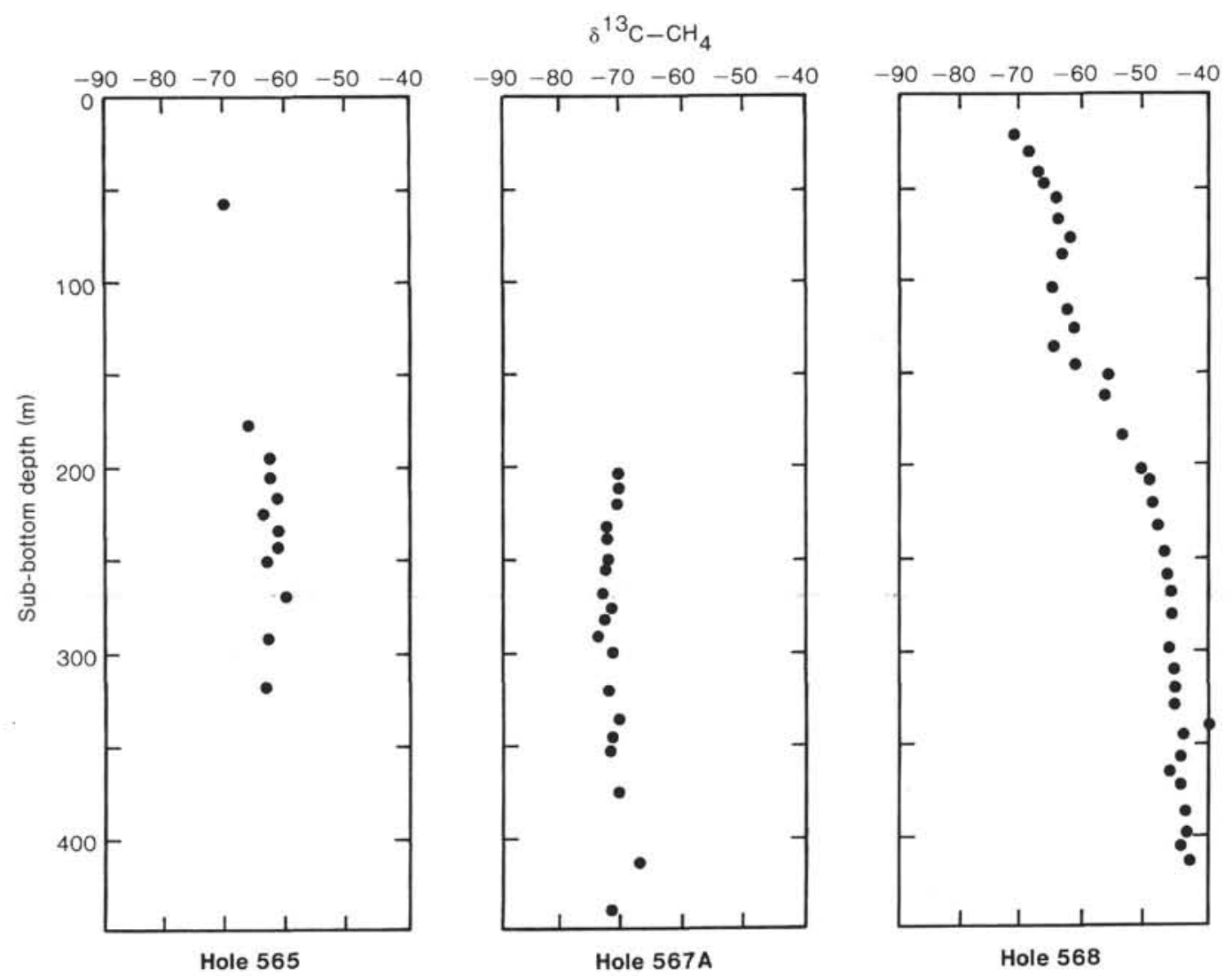

Figure 1. $\delta^{13} \mathrm{C}_{\mathrm{PDB}}$ of methane in vacutainer gas from Sites 565,567 , and 568 . 
ISOTOPIC ANALYSIS OF CORE GASES, SITES 565-570

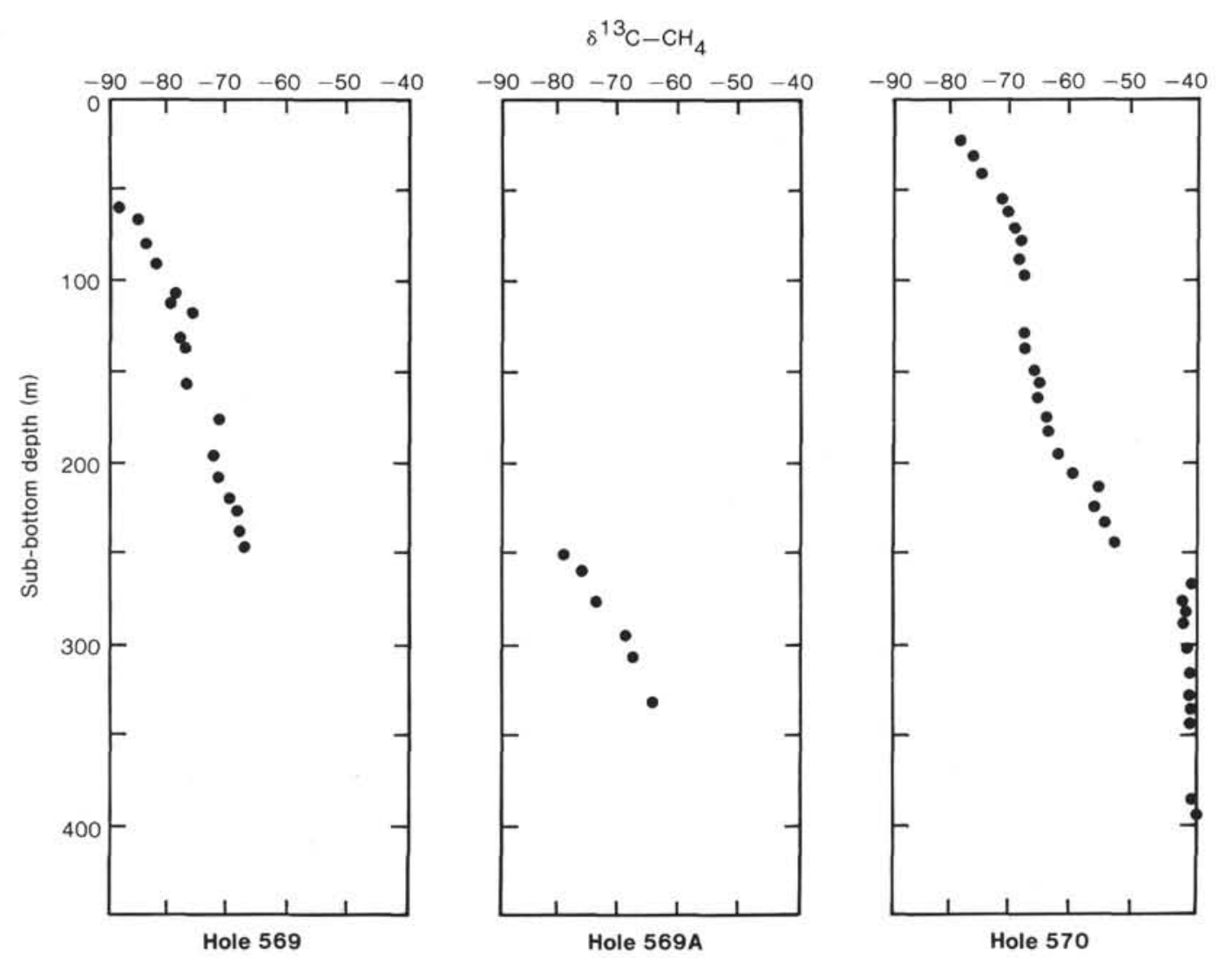

Figure 2. $\delta^{13} \mathrm{C}_{\mathrm{PDB}}$ of methane in vacutainer gas from Sites 569 and 570 .
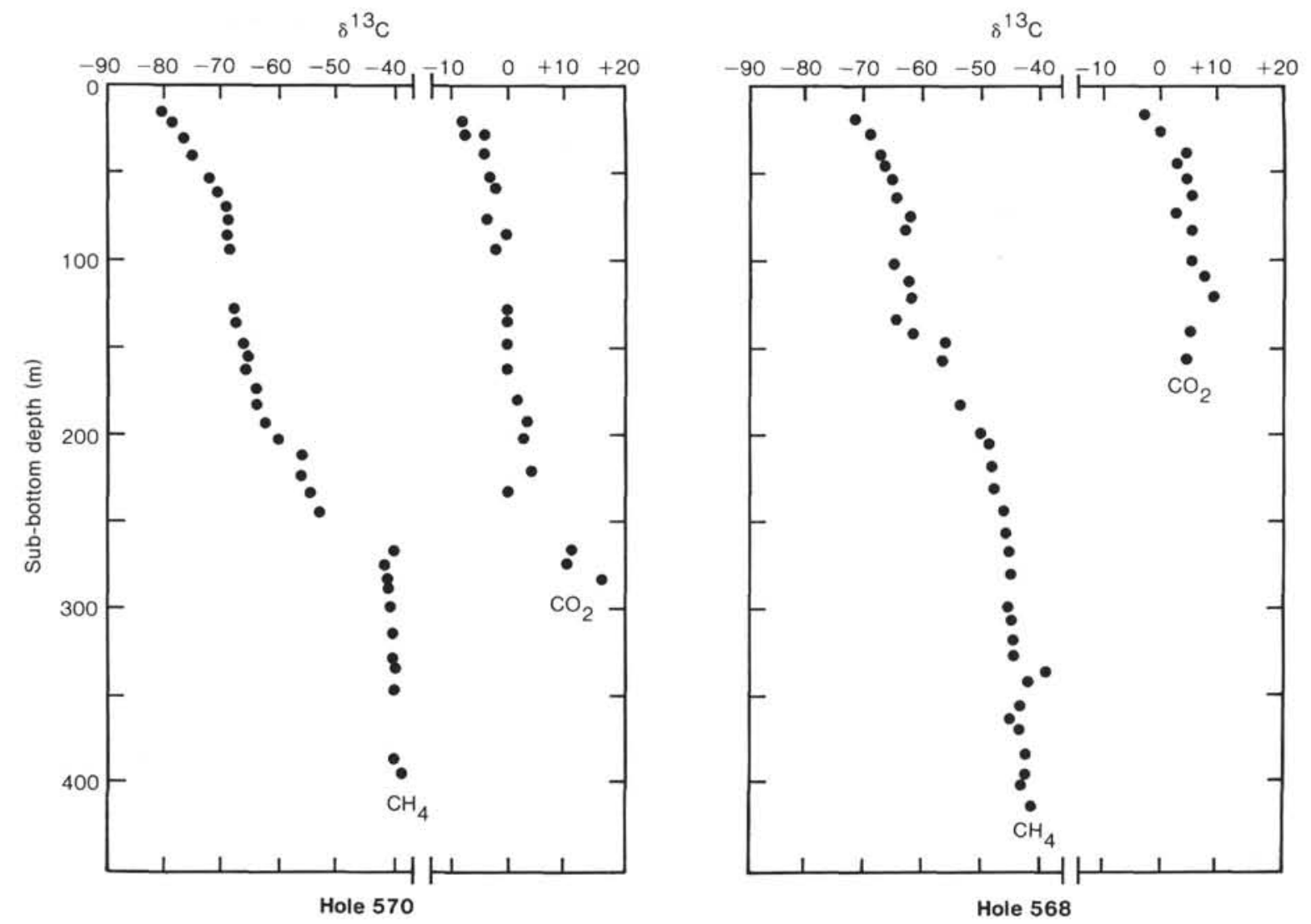

Figure 3. $\delta^{13} \mathrm{C}_{\mathrm{PDB}}$ of methane and of $\mathrm{CO}_{2}$ in vacutainer gas from Sites 568 and 570. 
decrease from about 90,000 near the surface to 440 at $274 \mathrm{~m}$, and then increase to 1900 at $317 \mathrm{~m}$. At the bottom of the hole there is a dramatic increase in ethane and higher hydrocarbon concentrations and a corresponding decrease in $C_{1} / C_{2}$ ratios to 190 and 85 in the serpentinite basement rocks at 387 and $395 \mathrm{~m}$, respectively. This contrasts with the steady increase with depth in concentrations of higher hydrocarbons at Site 568, more indicative of in situ production by diagenesis of sedimentary organic matter.

The hydrocarbon gases appear to be extremely immature at all the sites, judging by the isobutane $/ n$-butane and isopentane $/ n$-pentane ratios. Throughout each core, iso $/ n$ butane and pentane ratios are consistently greater than 1, and in many cases greater than 10 (Tables 1 through 6). Hunt, Huc, et al. (1980) have shown that iso $/ n$ pentane ratios are typically less than 1 in surface sediments, owing to biogenic contribution of the normal isomer. With increasing depth, diagenetic reactions preferentially generate iso-pentane, and iso $/ n$ pentane ratios up to 5 are found. With increasing burial, thermogenic reactions produce normal isomers, and the iso $/ n$ alkane ratio decreases with increasing maturity of the hydrocarbon gas, so that mature natural gases and petroleum-associated gases have ratios typically less than 1 (Maksimov et al., 1959; Reznikov, 1969; Astaf' ev et al., 1973).

It is possible that the ratios of butane and pentane isomers analyzed in the Sites $565-570$ sediments may be altered by migration or gas-hydrate formation. Leythaeuser et al. (1980) have shown that branched isomers are lost to the atmosphere at a faster rate than the normal isomers in short surface cores because of the apparently higher diffusion rate of the branched isomers through sediments. Since the relatively high hydrocarbon accumulations found in serpentinite at Sites 566 and 570 may be due to migration, the high iso/ $n$ butane and pentane ratios may be attributable to the more rapid migration of the branched isomers. The isomer ratios are not significantly different, however, in areas of presumed migration, compared with areas where the hydrocarbons appear to have been generated in situ. At Site 566, for example, the iso $/ n$ butane ratios at $120-130 \mathrm{~m}$ average 16 in a gas that has undoubtedly migrated into the basement rock at this depth. This value is similar to average ratios observed in cores from other sites $(565,568$, and 570$)$ that show no evidence of hydrocarbon migration.

Isomeric ratios of butanes may be changed by gas hydrate formations if a structure II type of hydrate is present, because this structure can accommodate isobutane but not $n$-butane (Hand et al., 1974), owing to the different molecular sizes of the isomers. Gas hydrates were observed at Site 565, 568, and 570; there were several gas hydrate occurrences at Site 570, including a 3-m section at $249 \mathrm{~m}$ sub-bottom (Kvenvolden and McDonald, this volume). Kvenvolden and McDonald (this volume) have suggested, however, that the gas hydrates here are structure I, which would have no effect on the ratios of the isomers of either butane or pentane. In addition, there appears to be no significant difference between butane and pentane isomer ratios in sections with extensive hydrate formation and in those sections where hydrates appeared to be absent. Thus, the presence of hydrates does not appear to affect the isomer ratios.

\section{$\mathrm{C}_{2}-\mathrm{C}_{5}$ Isotopic Composition}

The heavy carbon-isotopic values at Sites 566 and 570 for ethane and higher hydrocarbons indicate apparently immature diagenetic gas. At Site $570, \delta^{13} \mathrm{C}-\mathrm{C}_{2}$ values of core gases are fairly uniform, ranging from -24.2 to $-25.7 \% 0$ in six sections. Ethane in the massive gas hydrate at $249 \mathrm{~m}$ sub-bottom depth has a $\delta^{13} \mathrm{C}$ value of $-26.7 \%$ (Brooks et al., this volume). In serpentinite basement rocks at Site 570 , the $\delta^{13} \mathrm{C}-\mathrm{C}_{2}$ is $-24.3 \%$, and $\delta^{13} \mathrm{C}-\mathrm{C}_{3}$ values are -21.4 and $-21.6 \%$. Ethane and propane $\delta^{13} \mathrm{C}$ values are somewhat lighter in the serpentinite of Hole $566 \mathrm{C}$, and in both sections analyzed, the propane value was lighter than the ethane value. Our values agree well with a single measurement of $-25.4 \% 0$ obtained by Claypool et al. (1973) for ethane in a sample from DSDP Site 102.

$\delta^{13} \mathrm{C}$ values of ethane and higher hydrocarbons have been reported for a suite of 34 petroleum-associated gases (Galimov et al., 1970), a suite of mature to overmature natural gases (Stahl and Carey, 1975), and other natural gases and petroleum-associated gases (Fuex, 1977; Erdman and Morris, 1974). The isotopic values of ethane and propane in the cored sections from Sites 566 and 570 , especially site 570 , are among the heaviest reported, and do not appear to fit a maturity trend for natural gases from marine-derived organic matter established by Stahl and Carey (1975) and Stahl (1977). In this trend, methane, ethane, and propane are isotopically light in the least mature gases, and become progressively heavier with increasing maturity. Very immature gases such as those in this study appear to be much heavier than would be predicted.

In a study by Chung and Sackett (1979), involving pyrolysis of kerogens, coals, and petroleum samples, the earliest formed gas, in effect the least mature gas, was isotopically heavy compared with gas formed later. Chung and Sackett (1979) suggested that one explanation for this anomalously heavy gas could be isotopic heterogeneity in precursor molecules, with hydrocarbons formed earliest being generated from isotopically heavy regions of the precursor molecules. There is evidence from pyrolysis work, however, that catalytic decomposition of long-chain hydrocarbons in the presence of clay minerals, a process involving a carbonium-ion mechanism, generates initially isotopically heavy gaseous hydrocarbons (Sackett, 1978; Jeffrey, 1981). The higher concentrations of the branched-chain alkanes, isobutane and isopentane, in the immature sediments at Sites 565-570, may also be due to reactions involving the carboniumion mechanism (Hunt, Huc, et al., 1980; Hunt, Whelan, et al., 1980).

The methane isotopic profiles in the cores analyzed in this study are consistent with a biological origin for the methane. It seems likely, however, that the nonbiological reactions generating ethane and higher hydrocarbons in the deeper sediment sections also form methane. If the nonbiological methane concentration is assumed to be about 10 times the ethane concentrations (Claypool 
and Kvenvolden, 1983), biological methane is still more than $95 \%$ of the total methane in the gas from $387 \mathrm{~m}$ sub-bottom at Site 570 , which has the highest ethane concentration $(0.36 \%)$. This predominance of biological methane makes it difficult to establish whether methane generated in the earliest stages of diagenesis is anomalously heavy, as ethane and propane appear to be. Comparison of methane, ethane, and propane isotopic values in natural gases (Stahl and Carey, 1975; Fuex, 1977), petroleum gases (Galimov et al., 1970; Erdman and Morris, 1974), and pyrolysis gases (Jeffrey, 1981) indicate, however, that reactions which form heavy ethane and propane also form heavy methane.

If a comparison between the methane, ethane, and propane isotopic values in the overmature gases studied by Stahl and Carey (1975) and the sediment gases at Site 570 is valid, a methane isotopic value heavier than $-40 \%$ would be predicted for the nonbiological methane component. In sediment gases such as these, where methane is from a mixture of biological and nonbiological sources, the isotopic values of ethane and propane may be useful in arriving at an estimate of the isotopic value of the nonbiological methane component.

\section{SUMMARY}

$\delta^{13} \mathrm{C}-\mathrm{C}_{1}$ values at Sites $565,566,567$, and 569 were lighter than $-60 \%$, indicating a biogenic origin for these gases. $\delta^{13} \mathrm{C}-\mathrm{C}_{1}$ values in gases from Site 568 and 570 were lighter than $-60 \%$ in the upper parts of the cored sections, but in the lower parts the values approached $-40 \%$, much heavier than expected for biogenic gas. $\delta^{13} \mathrm{C}-\mathrm{CO}_{2}$ values, however, were also anomalously heavy at these sites, and the general parallel trends with depth of the $\mathrm{C}_{1}$ and $\mathrm{CO}_{2}$ isotopic values indicate that the isotopically heavy $\mathrm{C}_{1}$ is formed biogenically by reduction of heavy $\mathrm{CO}_{2}$.

$\mathrm{High}$ iso $/ n$ ratios of butane and pentane in these core gases indicate that the gases are thermally immature, consistent with low-temperature chemical diagenesis of indigenous organic matter as the source of ethane and higher hydrocarbons. $\delta^{13} \mathrm{C}$ values of ethane and propane are very heavy, especially at Site 570 , where $\delta^{13} \mathrm{C}$ values are heavier than $-27 \%$, and are among the heaviest values reported for these hydrocarbons. Consequently, the higher hydrocarbons in these gases do not fit established trends of $\delta^{13} \mathrm{C}$ values and maturity for hydrocarbons in more mature natural gases, which would predict much lighter $\delta^{13} \mathrm{C}$ values for the core-gas hydrocarbons. This indicates that the early stages of chemical diagenesis generate anomalously heavy ethane and propane, and by analogy, methane also, although this is difficult to prove, owing to the predominance of biogenic methane in the gases.

\section{ACKNOWLEDGMENTS}

We thank the individuals of the Glomar Challenger for their help during the sampling procedures. Research support for this study was provided by Gas Research Institute Grant 5081-363-0460 and Office and Naval Research Grant N00014-80-C-0113. Instrumentation support for this project was provided by the Center for Energy and Min- eral Resources at Texas A\&M University. The paper was reviewed by W. M. Sackett and George E. Claypool.

\section{REFERENCES}

Astaf'ev, V. P., Makhmudov, A. K., and Zhelonkin, A. I., 1973. Significance of isobutane/butane ratios in hydrocarbon gases in searching for petroleum (according to Baltic and Belorussian data). Tr. Vses. Neft. Nauchno-Issled. Geologarazved. Inst., 338:35-38.

Bernard, B. B., Brooks, J. M., Sackett, W. M., 1976. Natural gas seepage in the Gulf of Mexico. Earth Planet, Sci. Lett., 31:48-54. 1977. A geochemical model for characterization of hydrocarbon gas sources in marine sediments. Proc. Offshore Technol. Conf., 2934:435-438.

Chung, H. M., and Sackett, W. M., 1979. Use of stable carbon isotope compositions of pyrolytically derived methane as maturity indices for carbonaceous materials. Geochim. Cosmochim. Acta, 43: 1979-1988.

Claypool, G. E., and Kaplan, I. R., 1974. The origin and distribution of methane in marine sediments. In Kaplan, I. R. (Ed.), Natural Gases in Marine Sediments: New York (Plenum Press), pp. 99-139.

Claypool, G. E., and Kvenvolden, K. A., 1983. Methane and other hydrocarbon gases in marine sediments. Ann. Rev. Earth Planet. Sci. 11:299-327.

Claypool, G. E., Presley, B. J., and Kaplan, I. R., 1973. Gas analyses in sediment samples from Legs 10,11,13,14, 15, 18 and 19. In Creager, J. S., Scholl, D. W., et al., Init. Repts. DSDP, 19: Washington (U.S. Govt. Printing Office), 879-884.

Claypool, G. E., and Threlkeld, C. N., 1983. Anoxic diagenesis and methane generation in sediments of the Blake Outer Ridge, DSDP Site 533, Leg 76. In Sheridan, R. E., Gradstein, F. M., et al., Init. Repts. DSDP, 76: Washington (U.S. Govt. Printing Office), 391-402.

Erdman, J. G., and Morris, D. A., 1974. Geochemical correlation of petroleum. Am. Assoc. Pet. Geol. Bull., 58:2826-2337.

Fuex, A. N., 1977. The use of stable carbon isotopes in hydrocarbon exploration. J. Geochem. Explor., 7:155-188.

Galimov, E. M., Ivlev, A. A., and Kuznetsova, N. G., 1970. Carbon isotope composition of gaseous hydrocarbons in petroleum and the problem of their origin. Geochem. Int., 7:594-603.

Galimov, E. M., and Simoneit, B., 1982. Geochemistry of interstitial gases in sedimentary deposits of the Gulf of California, Leg 64. In Curray, J. R., Moore, D. G., et al. Init. Repts. DSDP, 64: Washington (U.S. Govt. Printing Office), 781-788.

Hand, J. H., Katz, D. L., and Verma, V. K., 1974. Review of gas hydrates with implications for ocean sediments. In Kaplan, I. R. (Ed.), Natural Gases in Marine Sediments: New York (Plenum), pp. 179-194.

Hunt, J. M., Huc, A. Y., and Whelan, J. K., 1980. Generation of light hydrocarbons in sedimentary rocks. Nature, 288:688-670.

Hunt, J. M., Whelan, J. K., and Huc, A. Y., 1980. Genesis of petroleum hydrocarbons in marine sediments. Science, 209:403-404.

Jeffrey, A. W. A., 1981. Thermal and clay catalyzed cracking in the formation of natural gas [Ph.D. thesis]. Texas AM University, College Station.

Leythaeuser, D., Schaefer, R. G., and Yükler, A., 1980. Diffusion of light hydrocarbons through near-surface rocks. Nature, 284: 522-525.

Maksimov, S. P., Yeremenko, N. A., Zukhovitskiy, A. A., Turkel 'Taub, N. M., Botheva, T. A., and Pankina, R. G., 1959. Regularities of change of composition of casing head gases along the stratigraphic section. Pet. Geol., 3:59-67.

Rice, D. D., and Claypool, G. E., 1981. Generation, accumulation, and resource potential of biogenic gas. Am. Assoc. Pet. Geol. Bull., $65: 5-25$.

Reznikov, A. N., 1969. On the geochemical significance of the ratio of $n$-butane and isobutane concentrations in petroleum gases. Geol. Neft. Gaza, 4:43-47.

Rosenfeld, W. D., and Silverman, S. R., 1959. Carbon isotopic fractionation in bacterial production of methane. Science, 130:1658-1659.

Sackett, W. M., 1978. Carbon and hydrogen isotope effects during the thermocatalytic production of hydrocarbons in laboratory simulation experiments. Geochim. Cosmochim. Acta, 42:571-580. 


\section{A. W. A. JEFFREY ET AL.}

Sackett, W. M., Nakaparksin, S., and Dalrymple, D., 1970. Carbon isotope effects in methane production by thermal cracking. In Hobson, G., and Speers, G. (Eds.), Advances in Organic Geochemistry, 1966: New York (Pergamon Press), pp. 37-53.

Stahl, W., 1977. Carbon and nitrogen isotopes in hydrocarbon research and exploration. Chem. Geol., 20:121-149.

Stahl, W., and Carey, B. D., 1975. Source rock identification by isotope analyses of natural gases from fields in the Val Verde and Delaware basins, West Texas. Chem. Geol., 16:257-267.
Summerhayes, C. P., and Gilbert, D., 1981. Distribution, origin and hydrocarbon potential of organic matter in sediments from the $\mathrm{Pa}$ cific margin of Guatemala. In Aubouin, J., von Huene, R., et al., Init. Repts. DSDP, 67: Washington (U.S. Govt. Printing Office), 595-599.

ZoBell, C. E., and Rittenberg, S. C., 1948. Sulfate-reducing bacteria in marine sediments. J. Mar. Res., 7:606. 